\title{
Bioethics and Human Rights in the Area of Health-related Research: A Brief Review of Resource
}

\author{
Bioética y derechos humanos en materia de investigación relacionada con la salud: Breve \\ revisión de recursos
}

Cotonieto-Martínez $E^{a}$

\begin{abstract}
:
Bioethics and Human Rights are knowledge fields that every health professional has to master to perform their work with quality and respect to human dignity, especially regarding health-related research. The purpose of this review is to identify the main documents that allow the researcher to be able to obey national and international ethical guidelines during the design, implementation, information management and evaluation of health-related researches. Promoting the use of this type of resources will strengthen the related procedures to produce scientific material about health respecting bioethical principles and protecting human rights.
\end{abstract}

Keywords:

Bioethics, Human rights, Research, Health

\section{Resumen:}

La Bioética y los Derechos Humanos son áreas del conocimiento que todo profesional de la salud debe dominar para desempeñar su labor con calidad y respeto a la dignidad humana, especialmente en materia de investigación relacionada con la salud. El propósito de la presente revisión es identificar los principales documentos que le permiten al investigador ser capaz de atender los lineamientos éticos nacionales e internacionales durante el diseño, implantación, gestión de información y evaluación de investigaciones relacionadas con la salud. Promover el uso de este tipo de recursos fortalecerá los procedimientos relacionados a la producción de material científico en salud desde una perspectiva de respeto a los principios bioéticos y protección de derechos humanos.

\section{Palabras Clave:}

Bioética, Derechos humanos, Investigación, Salud

\section{Introduction}

The term Bioethics was created by Van Rensselaer Potter in 1971. Currently, it is considered a very important science, where biological aspects that respond to physical laws and aspects related to ethics-moral conscience converge. Beyond the usual definition of "ethics for life", bioethics studies and reflects on human behavior regarding health, life and human rights; especially to deal with the advances of biological sciences. The principles of bioethics which are the basis of regulations are':

- Respect to the autonomy.

- Promotion of charity.

- Prevent low efficiency.

- Fair conduct.
The Human Rights are a set of benefits based on human dignity, established according to an international legal framework ${ }^{2}$, and in Mexico, on the Constitution. The respect to human rights depends on all of us and its enforceability is based on four principles ${ }^{3-4}$ :

Universality. It refers to equality of rights for all people, regardless of specific conditions or characteristics ${ }^{3-4}$.

Principle of Interdependence. Highlights the link between human rights, that is, they must be respected and protected as a whole.

Principle of Indivisibility. No right is inalienable, under any circumstances, since violating one of them is violating the rest of them. 
Principle of Progressiveness. Refers to the obligation of the State has of assuring the development of human rights and the prohibition of setbacks.

On the other hand, research related to health is every activity oriented to develop procedures and knowledge related to human beings health, with the objective of generalizing through observations, clinical trials, and epidemiological studies 5 .

Through different resources, the use of concepts of bioethics and human rights (and their interaction) is shown, as they have been used to formulate valuation criteria about acts universally accepted by the scientific community regarding research related to health, especially in those designs in which human beings participate.

Some of the most representative resources are reviewed below, making special emphasis in those sections related to the compliance of the principles of bioethics, in the framework of human rights protection during a research.

\section{Universal Declaration of Human Rights}

Human Rights have turn to be very important at an international level with the Universal Declaration of Human Rights of the United Nations in 1948. The declaration emerges as a result against abusive actions during the World War and is focused on recognizing humans' dignity and equality; addressing the need of establishing mechanisms of protection and promotion of human rights, working with the international community to guarantee people's progress and elevate their life quality. The Declaration includes 30 measures. For the purpose of this paper, six of them are mentioned below ${ }^{6}$ :

1. All human beings are born free and equal in dignity and rights.

2. Everyone is entitled to all the rights and freedoms set forth in this Declaration, without distinction of any kind, such as race, color, sex, language, religion, political or other opinion, national or social origin, property, birth or other status.

3. Everyone has the right to life, liberty and security of person.

4. Impartiality and equality in procedures about the determination of rights and obligations.

5. Everyone has the right to participate in the cultural life of the community, to enjoy the arts and to share in scientific advancement and its benefits. Everyone has the right to the protection of the moral and material interests resulting from any scientific, literary or artistic production of which he is the author.

6. Nothing in the Declaration may be interpreted as implying for any State, group or person any right to engage in any activity or to perform any act aimed at the destruction of any of the rights and freedoms set forth

herein.

\section{Declaration of Helsinki}

Developed by the World Medical Association in 1964. It emerges to address the need of establishing ethical suggestions and guidelines to carry out conducts oriented to biomedical research in persons. The declaration has three sections which are briefly described below?

1. Introduction. There must exist consistency between the research and the universally accepted scientific principles; any experimental design must be submitted to the evaluation of a proper committee; research must be performed by qualified people under supervision; thorough evaluation of foreseeable risks and benefits; preserve people safety (reduce risks); suspension of activities in case of clear risks; granting information about the study's objectives, methods, benefits, and risks to participants for them to be able to make a free decision (informed consent); establishing actions to avoid coercion and, in special cases with minors or legal incompetence, the guardian will make the decision (he must also sign an informed consent when possible); besides, the protocol should always contain a statement of the ethical considerations involved and should indicate that there is compliance with the principles enunciated in this declaration.

2. Medical research combined with professional medical care (clinical research). Includes the possibility of using new procedures if they give any hope of saving lives, restoring health or healing pain; evaluate the benefits and risks of new procedures compared to those already available; apply the best confirmed procedure (including a control group); the therapeutic relationship must not depend on the patient participating or not in the study; if the informed consent is not necessary, the motive must be explained in the protocol.

3. Biomedical not therapeutic research involving people (biomedical research, not clinical). The life and health of each participant must be protected; voluntary participation, or healthy people or people who are not related to the experimental protocol; suspend the research if it is considered to be harmful and put special interest on the 
well-being of people above the interest for science and society.

\section{International Covenant of Economic, Social and Cultural Rights}

It was approved on 1966 by the General Assembly of the United Nations (UN). Mexico joined the Covenant in 1981. It has $\mathrm{V}$ sections, with a total of 31 Articles which, according to the Universal Declaration of Human Rights, rights and obligations are established to promote the universal and effective respect of human rights and liberties $^{8-9}$.

According to Article 12, talking about health right does not refer to a person enjoying an optimal health or to highly expensive governmental health facilities; it refers to the implementation of public policies and action plans that allows the access for all public to health care in a short period of time, covering as much population as posible $e^{8-9}$.

Additionally, Article 15 of the Covenant talks about the duty of government regarding scientific research and knowledge (preservation, development and promotion) by pointing out the right that every person has to use and enjoy scientific progress and how it can be applied to the health right $^{8-9}$.

Besides, in the year 2000, the Committee for Economic, Social and Cultural Rights reviewed the International Covenant of Economic, Social and Cultural Rights adopted since 1966, and apart from recognizing health as an inclusive right, it emphasizes the link (and dependency) it has with other rights such as the right to have food, housing, work, education, the right to participate, to equality, to not be tortured, to private life, to information Access, and to enjoy scientific progress. The right to health not only depends on health care quality in terms of the health system, but it is also closely linked to basic determinant factors ${ }^{8-9}$.

\section{International ethical guidelines for health- related research}

In 1982, the Council for International Organizations of Medical Sciences (CIOMS), in collaboration with the World Health Organization (OMS) made the first version of "International ethical guidelines for health-related research", with the objective of giving ethical objectives internationally approved to apply them in the design, development, evaluation and publication of scientific studies ${ }^{5}$

Within the reviews of the Declaration of Helsinki, created to deal with the ethical aspects related to large-scale trial suggestions (HIV/AIDS pandemic) and issues related to biotechnology and multinational trials, experimentation with vulnerable groups; the second review of the international ethical guidelines was carried out in en 1993, including an approach addressed to emphasize the benefits of the population who participated ${ }^{5}$.

The third version, in 2002, was oriented to specify some provisions about clinical trials sponsored and executed in low-resource environments. In 2009, a series of ethical guidelines for epidemiological studies was published (process started in 2003). Finally, that same year one more review was started to generate the fourth version, which was published in 2016. It expanded the approach of "biomedical research" to "health-related research". The guidelines included in that version are mentioned below which must be considered and identified by the researcher:

- Scientific and social value and respect for human rights.

- Research conducted in low-resource settings.

- Equitable distribution of benefits and burdens in the selection of individuals and groups of participants in research.

- Potential individual benefits and risks of participating in a research.

- Choice in control in clinical trials.

- Caring for participants' health needs.

- Community engagement in the research.

- Collaborative partnership and capacity-building for research and research review.

- Individuals capable of giving informed consent.

- Modifications and waivers of informed consent.

- Collection, storage and use of biological materials and related data.

- Collection, storage and use of data in health-related research.

- Reimbursement and compensation for research participants.

- Treatment and compensation for research-related harms cause by a research.

- Research involving vulnerable persons and groups.

- Research involving adults incapable of giving informed consent.

- Research involving children and adolescents.

- Women as research participants.

- Pregnant and breastfeeding women as research participants.

- Research in disasters and disease outbreaks. 
- Cluster randomized trials.

- Use of data obtained from the online environment and digital tools in health-related research.

- Requirements for establishing research ethics committees and for their review of protocols.

- Public accountability for health-related research.

- Conflicts of interest.

\section{Bioethics and Human Rights}

In October 2005, it was approved the Universal Declaration on Bioethics and Human Rights at the General Conference of the United Nations Educational, Scientific and Cultural Organization (UNESCO). The states members of this declaration (and the international community) engaged to respect and apply fundamental bioethical principles.

The declaration recognizes the relationship between ethics and human rights. It implies that every human being has the right to benefit from technological and scientific advances in a framework of respect to fundamental liberties of the person ${ }^{10}$.

This Declaration covers ethical aspects associated to the medical environment, life sciences and technologies applied to humans, always considering the social, legal and environmental sphere of individual, groups, communities and enterprises, both public and private ${ }^{10}$.

It establishes principles addressed to guide decisionmaking and practices, in the fields previously mentioned ${ }^{10}$ that are useful to guide the field of research with human beings:

- Human dignity and human rights.

- Benefit and harm.

- Autonomy and individual responsibility.

- Consent.

- Persons without the capacity to consent.

- Respect for human vulnerability and personal integrity.

- Privacy and confidentiality.

- Equality, justice and equity.

- Non-discrimination and non-stigmatization.

- Respect for cultural diversity and pluralism.

- Solidarity and cooperation.

- Social responsibility and health.

- Sharing of benefits.

- Protecting future generations.

- Protection of the environment, the biosphere and biodiversity.

Finally, it includes some provisions about interrelation and complementarity of principles, limitation to principles' application, and some exceptions regarding interpretation (actions that are against human rights, fundamental liberties and human dignity) ${ }^{10}$ and that allow decisionmaking also regarding research.

\section{Regulations of the General Health Law regarding Health-Related Research}

They were published in 2014 in the Official Journal of the Federation. The regulations include 132 articles, distributed in 9 chapters and have the objective of having a legal framework for health-related research actions in Mexico. In general, these are the regulations:

1. General provisions.

2. Ethical aspects of research in human beings.

3. Research on Prophylactic, Diagnosis, Therapeutic and Rehabilitation Resources.

4. Biosafety research.

5. Internal commissions of health institutions.

6. Execution of research in health care institutions.

7. Research including use of animals for experimentation.

8. Safety measures.

9. Follow-up and compliance.

\section{Discussion and conclusions}

The relevance of human rights has to do with its function at an individual, social and structural level as they are fundamental to: achieve a comprehensive development of people, create conditions to actively participate in the democratic life and public affairs, establish limitations to the actions of institutions to prevent abuses or negligence, and increasing autonomy that allows making a desirable life plan.

The community of researchers, sponsors, ethics committee on research and health authorities, they have the obligation of evaluating the social and scientific value, the qualifications of research staff, and the respect of human rights and the good state of research protocols.

The scientific and social relevance has to do with the potential information quality, suitability to tackle important health problems, and the contribution in terms of clinical practices or public policies that improve the quality of health care services; besides, it must have a clinically solid design and provide ways to collect information that other 
way is impossible to collect. Bioethics and Human Rights are involved in all of this.

Additionally, the results of health-related research have an impact on patients, health professionals, researchers, actors in public policies formulation (including officers), pharmaceutical enterprises, and other instances. This is why they must be carried out with the highest quality possible as they are going to become decisions that will have an impact on health, resource management and social well-being.

The documents mentioned in this review are useful to build better conditions in terms of scientific production and optimization of clinical procedures, in order to protect and promote health around the world.

It is worth mentioning that, although through time a great amount of documents have been written regarding healthrelated bioethics and human rights, the documents mentioned above are useful to provide more legal support to research actions.

Researchers will be able to identify strong areas and areas of opportunity regarding good practices in health-related research. There is going to be an increase of timely decision-making possibilities and a comprehensive route of action, with a bigger scope and with better results regarding bioethical principles during the design, implementation, information management, and evaluation of research projects.

\section{Bibliography}

[1] Velasco-Suárez, M. Derecho y salud, su protección y fomento. Bioética para el respeto al derecho a la vida y promoción de la salud. Muñoz, M. Temas selectos de salud y derecho. México: UNAM. [Internet]. 2002. Disponible en: https://biblio.juridicas.unam.mx/bjv/detalle-libro/357temas-selectos-de-salud-y-derecho

[2] Instituto de Investigaciones Jurídicas. La protección de la salud en la comisión de los derechos humanos. [Internet] 2002. Disponible en: https://archivos.juridicas.unam.mx/www/bjv/libros/1/357/14.pdf

[3] Comisión Nacional de los Derechos Humanos. ¿Qué son los derechos humanos? [Internet]. $2017 . \quad$ Disponible en: http://www.cndh.org.mx/Que_son_Derechos_Humanos.

[4] Organización Mundial de la Salud. Veinticinco Preguntas y Respuestas sobre Salud y derechos humanos. [Internet]. 2002. Disponible en: http://www.who.int/hhr/activities/Q\%26AfinalversionSpanish.pdf

[5] International Organizations of Medical Sciences. International Ethical Guidelines for Health-related Research Involving Humans. [Internet]. 2016. Disponible en: https://cioms.ch/wpcontent/uploads/2017/01/WEB-CIOMS-EthicalGuidelines.pdf

[6] Naciones Unidas. Declaración Universal de Derechos Humanos. [Internet]. 1948. Disponible en: http://www.un.org/es/universaldeclaration-human-rights/

[7] World Medical Association Declaration of Helsinki. Ethical Principles for Medical Research Involving Human Subjects. [Internet]. 2008.
Disponible
http://www.anmb.mx/pdf2014/breviario_declarachelsinki2008.pdf

8] United Nations Human Rights. Office of the Gigh Comissioner. International Covenant on Economic, Social and Cultural Rights. [Internet]. $1966 . \quad$ Disponible en: https://www.ohchr.org/en/professionalinterest/pages/cescr.aspx

[9] Comisión Nacional de los Derechos Humanos. Pacto Internacional de Derechos Humanos, Sociales y Culturales, y su Protocolo Facultativos. [Internet]. 2012. Disponible es: http://www.cndh.org.mx/sites/all/doc/cartillas/7_Cartilla_PIDESCyPF. pdf

[10] Organización de las Naciones Unidas para la Educación, la Ciencia y la Cultura. Declaración universal sobre Bioética y Derechos Humanos. [Internet]. 2005. Disponible en: http://portal.unesco.org/es/ev.phpURL_ID=31058\&URL_DO=DO_TOPIC\&URL_SECTION=201.html

[11] Reglamento de la Ley General de Salud en Materia de Investigación para la Salud. Diario Oficial de la Federación, México. [Internet]. 2014. Disponible

http://www.salud.gob.mx/unidades/cdi/nom/compi/rlgsmis.html. 